\title{
THE YOUTHS' PERCEPTIONS OF SEXUALITY IN THE LIMPOPO PROVINCE OF SOUTH
} AFRICA

\section{Thelmah X Maluleke}

D Litt et Phil

Head, Department of Public Health, University of Venda, Thohoyandou

Corresponding author: tmaluleke@univen.ac.za

Keywords: sexual behaviour; sexual desire; sexual health; sexual intercourse; sexuality

\begin{abstract}
This study was a qualitative, exploratory and descriptive study, conducted in the Vhembe District Municipality of the Limpopo Province in four selected villages. The purpose of the study was to explore and describe the views of young people regarding sexuality. Data were collected from October 2004 to January 2005 using focus group discussions, key-informant interviews, semi-structured interviews and observation. Young people's views about sexuality were centred around heterosexual sexual intercourse and the prevention of sexually transmitted infections (STIS), prevention of the Human Immunodeficiency Virus (HIV) and Acquired Immune Deficiency Syndrome (AIDS), use of contraceptives, performance of sex, activities that take place during intercourse for example touching, kissing and penetration by the man's penis, making babies and use of condoms.
\end{abstract}

\section{OPSOMMING}

Hierdie studie was 'n kwalitatiewe, verkennende en beskrywende studie, onderneem in die Vhembe Distrik Munisipaliteit van die Limpopo Provinsie, in vier uitgesoekte dorpies. Die doel van die studie was om die jeug se beskouing van seksualiteit te verken en te beskryf. Data is ingesamel vanaf Oktober 2004 tot Januarie 2005 deur gebruik te maak van fokusgroepbesprekings, onderhoude met sleutelinformante, semi-gestruktureerde onderhoude en waarneming. Die jongmense se beskouing van seksualiteit was gesentreer rondom heteroseksuele geslagsomgang en die voorkoming van seksueeloordraagbare siektes, voorkoming van Menslike Immuungebrekvirus (MIV) en Verworwe Immuniteitsgebrek Sindroom (VIGS), gebruik van voorbehoedmiddels, die seksdaad, aktiwiteite wat plaasvind tydens seksuele omgang byvoorbeeld aanraking, soen, penetrasie van die man se penis, die maak van babas en die gebruik van kondome. 


\section{INTRODUCTION}

Human beings, women and men, young and old, abled and disabled, are sexual beings. As sexual beings they need to express and enjoy their sexuality throughout their lives and take responsibility for their sexual behaviour. They need to exercise their sexual rights and make decisions about their sexuality consistent with their own values. They need freedom from fear, shame, guilt and false beliefs that might inhibit their sexual responses and impair their sexuality (Koontz \& Conly, 1994:3). As sexual beings, they have the ability to make choices, and express love and intimacy consistent with their own values. However, society has put some control measures in place over sexuality, particularly that of women, by reducing it to mere sexual intercourse and therefore relegating it to the private space (National Federation of the Red Cross and Crescent Society, [Sa]:4). The problem with relegating sexuality to the private space is that society relinquishes its responsibility to protect the vulnerable: women, youth, children, the disabled and the aged. For example, rape by a sexual partner, relative or parent, sexual harassment, and any other forms of sexual violence that occur within the private space become a private matter and therefore go unchallenged by society (Kenya Women's International Association, 1993:3-5).

In many communities young people face different challenges related to their sexuality: environment, age, gender, poverty, unemployment, diseases, which have an influence on their perception of the world and themselves. Lack of information and guidance about sex and sexuality make young people vulnerable to physical, emotional and economic exploitation. In many societies the family and community traditionally provided the youth with information and guidance about sex and sexuality as part of their initiation into adulthood. However, societal changes, for example, poverty, rapid urbanisation, migration, education and religion, have destabilised this traditional way of sharing information and knowledge in many families and communities. Many parents leave their families to seek work on commercial farms and in towns and cities, leaving their children with no guidance and support. According to the International Planned Parenthood Federation (2002:1-3), the destabilisation of the family and traditional community networks have resulted in young people receiving conflicting messages about sexuality from siblings, peers and the mass media which are often not validated by a trusted adult. This article describes the perceptions of young people regarding sexuality and factors that influence their perceptions.

\section{STATEMENT OF THE PROBLEM}

In their daily lives young people are exposed to mixed information about sexuality from their parents, teachers, peers, and religious leaders, which they need to use to develop their own sexuality and sexual behaviour. In their confusion they tend to expose themselves, intentionally or unintentionally, to sexual health risks, for example, to unprotected sex and rape. There is a strong realisation of the need for sexual health programmes in order to guide young people in developing healthy sexual behaviour and taking responsibility for their own lives. The Department of Education in South Africa has introduced a comprehensive sexuality education programme commonly known as life skills or life orientation in schools to assist young people to take responsibility for their lives (Maluleke, 2003:62). The discovery of the HIV and AIDS virus in humans has dramatically increased the need for sexuality education in all communities. Many models have been developed and implemented in an effort to deal with young people's sexual needs and to curb the scourge of HIV and AIDS. These include youth-friendly clinics, the multi-service youth centre model and community outreach programmes (Crewe, 1996:8).

South Africa remains one of the countries with a high HIV and AIDS prevalence rate. There are currently about 7.8 million people who are infected with HIV and AIDS in South Africa (UNAIDS, 2006:11). The latest South African statistics suggest that among antenatal clinic attendants, about $70 \%$ of the HIV positive pregnant women are below the age of 30 years (Department of Health Report, 2007:5). The HIV and AIDS prevalence rate among pregnant women in the Limpopo Province has increased from $19.3 \%$ to $21.5 \%$ based on the October 2005 statistics collected by the Department of Health. The prevalence rate among young people aged 20 - 24 was estimated to be $30 \%$, with the highest prevalence rate of about $40 \%$ being among women aged 25 - 29 years. In addition, sexually transmitted infections and teenage pregnancies are still a problem (Department of Health Report, 2007:5). 
The objectives of this study were to determine:

- $\quad$ the perceptions of young people regarding sexuality; and

- $\quad$ factors influencing young people's perception of sexuality.

\section{SIGNIFICANCE OF THE STUDY}

The study comes at a time when life orientation programmes are offered in many schools in South Africa, including those in rural areas, where issues of sexuality are discussed. As young people are the main targets of sexuality education programmes, getting their views about sexuality could influence the direction and content of such programmes.

\section{LIMITATIONS OF THE STUDY}

Collecting data about sexuality in a society where issues related to sexuality were not discussed publicly, except in cases where deviation from the norms and standards of the society had occurred, was quite daunting. The first challenge was finding a concept in Xitsonga that had a similar meaning to sexuality as described below. There was no word or phrase that could be used without leading the participants in a particular direction in their definition of sexuality. For example, the following phrase is commonly used over the radio and among health workers when discussing sexuality: "timhaka ta masangu" of which the direct translation is "issues about the grass mat". The phrases often used for sexual intercourse are: "vuxaka exikarhi ka wanuna na wansati" meaning "the relationship between a man and a woman"; "timhaka ta rirhandzu/marhandzu" meaning "issues about love"; and "timhaka to vugangu" meaning "issues about love affairs". However, in many instances these phrases were used interchangeably for sexual intercourse. To place this discussion in context, the phrases indicated above were often used to replace a taboo word "ku kundzana", the phrase meaning sexual intercourse in Xitsonga. Other words were "vusati" and "vununa". These words suggest that femininity or the female and masculinity or the male were being discussed. The second challenge was getting the participants to discuss issues of sexuality in a churchyard, which is the only place available for community meetings. To deal with both challenges a story about male virginity was used as an ice breaker.

\section{CLARIFICATION OF CONCEPTS}

\section{Sexuality}

Sexuality is a broad concept which has many definitions, ranging from defining it as gender; sexual orientation; sex acts; physical social expression; social differences linked to sexual identity and behaviour; and an expression of sexual feelings. According to Intervention for Support Healing Awareness (IFSHA) (2005:1), sexuality refers to "the totality of being human, not simply the genital acts. Sexuality is concerned with the biological, psychological, sociological and spiritual variables of life that affect personality development and interpersonal relations. It includes one's selfperception, self-esteem, personal history, personality, concept of love and intimacy and body image".

Sexuality does not mean sexual activity only; it is a concept that encompasses sexual behaviour and function, as well as the individual's awareness of her or his body. Feminists see the reduction of sexuality to sexual intercourse as a patriarchal definition based on men's needs and satisfaction. Sexuality is further described as a form of expression that begins at birth and continues throughout the individual's life, involving her or his physical, emotional, social and intellectual aspects. Sexuality includes the full range of issues that relate to the sexes and the relationships between them. It is influenced by the societal norms and social conditioning around sexual behaviour (Kenya Women's International Association, 1993:3-5).

According to the International Federation of Red Cross and Red Crescent Societies ([Sa]:4), sexuality refers to the way people feel about themselves (self-esteem); the way they feel about and their bodies (body image); the roles they adopt and the expectations other people have of them (social roles); and the way in which they relate to others (relationships).

Sexuality is shaped by how individuals feel about themselves and their bodies and their belief in their abilities. In other words, if we like ourselves, feel comfortable with our bodies, and believe in our abilities, we are more likely to be comfortable with our sexuality (Goosen \& Klugman, 1996:248). 


\section{Youth}

The United Nations (UN) defines young people as individuals who are female or male aged between 15 and 24 years (O'Higgins, 1997:1). In South Africa young people are considered to be females or males aged from 14 to 35 years (National Youth Commission, 1997:5). In this study young people refers to both females and males from 15 to 25 years of age.

\section{THEORETICAL ORIENTATION}

This study is based on the premise that an individual's environment from birth to death affects her/his attitude to sexuality and sexual activities. The environment in this case refers to the individual's culture, which includes family, peers, religion, school, communication, law, economy, media and decision-making skills. The culture and society in which an individual grows up and lives, largely determines how that individual feels about her or his sexuality (Goosen \& Klugman, 1996:248). The societal norms and environment in which young people find themselves, including poverty, violence, sexual abuse, rites of passage and life orientation programmes, could have an impact on their understanding of their own sexuality. It is therefore important to determine their views concerning sexuality in order to develop sexual health programmes that address their own understanding of sexuality and sexual health needs.

As the youth come of age, gender norms give them clues to what they should or should not know about sexuality, how they should interact with the opposite sex and whether or not they should have access to reproductive health information services. Gender norms influence developmental changes among the youth by inhibiting their self-confidence, access to information, and opportunities to acquire skills. Constraints on girls' knowledge of sexuality hamper their understanding of the reproductive system, disease transmission and prevention. Girls' communication and negotiation skills are restricted by the leading role expected of males in decision-making. The gender differences between male and female determine the power dynamics that influence the way girls and boys experience intimacy, sexuality and reproduction. Gender-based power dynamics and stereotypes increase vulnerability and risks by affecting both boys' and girls' ability to make decisions related to their reproductive health and their taking ac- tion to protect themselves. Gender-related expectations compromise girls' knowledge and ability to protect themselves against unwanted pregnancy, STIs and violence (African Youth Alliance, [Sa]:1-2).

Although sexuality is celebrated in many communities including the community under study, its celebration is often used to reinforce societal roles that perpetuate the oppression of women and the use of women as reproductive and sexual instruments. On the other hand, the poverty prevailing in the communities affects both male and female children in the communities. Cultural traditions, scant economic resources and limited opportunities lead to the marginalisation of young girls. Many young people, girls in particular, are manipulated or pressured into sexual activities before they are ready in order to alleviate the family's poverty, which results in a great deal of emotional pain (African Youth Alliance [Sa]:1-2). For example, young girls are often forced into arranged marriages in order to get "lobola" as well as prostitution and girl child trafficking in order to get some money for the family.

\section{STUDY DESIGN}

The study was designed as a qualitative, exploratory and descriptive research project conducted in the Vhembe Municipality of the Limpopo Province of South Africa because its purpose was to explore and describe the views of young people regarding sexuality. The youths' perceptions, beliefs and attitudes towards sexuality were documented and discussed. The study was conducted in four villages where the researcher was already doing some work on puberty rites for girls and this study was a follow-up to the previous projects.

The population of the study was all young people aged between 15 and 25 years living in the four selected villages during the period October 2004 to January 2005. The researcher divided each village into four sections, A, B, C and D and one focus group discussion was conducted in each section. The mixed-gender focus group discussion included young people from the four sections of each village. The selection of the participants was done through a convenient sampling method. That is, the first twelve to fifteen young people (with parental consent, if they were younger than 18 years) to arrive at the venue were allowed to participate in the focus group discussions. All participants voluntarily 
participated in the focus group discussions or interviews without coercion from the researchers or community members.

\section{DATA COLLECTION}

Data were collected from October 2004 to January 2005 using the following methods: focus group discussions, key-informant interviews, semi-structured interviews and observation as indicated in Table 1 below.

\section{Focus group discussions}

Five focus group discussions were conducted with young people in each village. These were conducted as follows: two female only, two male only and one mixedgender focus group discussion (see Table 1). The reason for having a focus group with both females and males was to get an opportunity to observe gender relations among the youth in these four villages, and how they behave and communicate in the presence of the opposite sex. The focus group discussions were held on different days to prevent the groups from influencing one another. The duration of each focus group session was about one hour and thirty minutes. The data were gathered through tape recordings, later transcribed verbatim and then translated into English by a professional translator. A focus group discussion is described as "a group discussion with people who have been selected, because they share certain characteristics, which are relevant to the topic to be discussed". It is a planned discussion usually comprising six to ten people and is designed to obtain information on participants' belief and perceptions within a defined area of interest (World Health Organization, 1994:24).

In this study the focus group discussions were used to get the views of young people about sexuality, their own bodies, sexual desire and factors that influenced them. Facilitating the first group was quite a challenge as the participants showed great discomfort with what the research was all about. Despite the assurance of confidentiality, the discussions did not start spontaneously due to shyness about discussing issues of sexuality in a group as it happens in many other communities and families. A story about male virginity was introduced and it worked as an ice breaker. The discussion around the story became lively and fruitful and issues related to the study were also discussed. The story was also used with all subsequent groups. The mixed group highlighted male gender relations among young people in these villages. The females were very quiet and the males very vocal and dominant in all villages.

\section{Key-informant interviews}

Key-informant interviews are interviews that are conducted with people who have a special position in the community. Key-informants possess special knowledge and are willing to share this with the researcher. They have access to the culture under study in a way that the researcher lacks (Hudelson, 1994:43).

Table 1: Data collection methods used

\begin{tabular}{|l|l|l|l|l|l|}
\hline Data collection method & $\begin{array}{l}\text { Total number } \\
\text { conducted per } \\
\text { village }\end{array}$ & $\begin{array}{l}\text { Total number } \\
\text { conducted }\end{array}$ & $\begin{array}{l}\text { Total number of } \\
\text { participants }\end{array}$ & Gender \\
\hline & & & & Females & Males \\
\hline Focus group discussion & 5 & 20 & 212 & 104 & 108 \\
\hline Key-informants & 4 & 16 & 16 & 12 & 4 \\
\hline $\begin{array}{l}\text { Semi-structured interviews } \\
\text { (one-to-one) }\end{array}$ & 6 & 24 & 24 & 16 & 8 \\
\hline Observation & $\begin{array}{l}\text { The researcher observed and recorded the village outlay (setting), } \\
\text { environment and activities of young people in each village in an unstructured } \\
\text { manner. }\end{array}$
\end{tabular}


Four key-informant interviews per village were conducted with the following participants: one life-orientation teacher (female), one pastor (male), one parent (female or male) and one vukhomba elder (female). It was difficult to get adults to participate in large numbers as it was the tillage period and many of them were in the fields or preparing for the festive season. The author was able to convince 12 adults to participate. Some males would not participate as key-informants, indicating that issues of youth sexuality needed input by women, as they were the ones who were responsible for the children.

\section{Semi-structured interviews}

Semi-structured interviews were held in each village with six individual young people, four females and two males, using a pre-tested guide. It was difficult to get participants for the one-to-one interviews, because participants felt that the interviews might become too personal and they would not be comfortable with that. The four females and two males in each village were recruited from the participants of the focus group discussion on a voluntary basis only. Some of the participants were married.

\section{Observation}

The observation method was mainly used by the researcher to understand the environment and circumstances that surround young people outside their home and school environment in each village. For example, young people were observed at entertainment centres, street activities, religious activities, fishing and activities related to outdoor chores (fetching firewood and water). Furthermore, it assisted the researcher during the analysis of data to understand what the participants were referring to in their discussions.

\section{DATA ANALYSIS}

The collected data were transcribed verbatim from the tape recordings, translated into English and analysed. Individual analysis of the transcriptions was done and categories were formed to allow the researcher to identify similarities, differences and relationships. The developed categories were then grouped into themes. The process of analysing the qualitative data described by Maier, Gorgen, Kielmann, Diesfeld and Korte (1994:86) and Creswell (1994:153-156) as a guide to developing categories and themes, were employed here. The following themes were developed: Perceptions about sexuality and factors influencing sexuality/factors encouraging sexual activities.

The views of each participant were recorded and transcribed verbatim and then translated into English. The assistance of peers was sought to help with the examination of transcripts and field notes to ensure reliability. A professional translator was used to check the English version and some parts that needed the expertise of a translator to ensure trustworthiness. The findings of this study will not necessarily be applicable to other communities and the findings can therefore not be generalised to all young people in the Limpopo Province. However, similar results could be found if similar studies were conducted in the same setting.

\section{ETHICAL CONSIDERATIONS}

Permission to collect data in the villages was sought from the community leaders where the study was conducted. Informed consent was obtained from each research participant before participating in the focus group discussion and interviews. In addition to that parental consent was sought for young people below the age of eighteen years before they were allowed to participate. Participants were informed about their right to withdraw from the discussions if they experienced any discomfort with the discussions. Anonymity of the participants was maintained and an assurance was given that all information would be treated in absolute confidence. All participants were assured of the maintenance of confidentiality.

\section{RESULTS AND DISCUSSIONS}

\section{Perceptions about sexuality}

Views about sexuality (one of the major themes the qualitative data was categorised into) were centred around heterosexual sexual intercourse, the prevention of STIS, prevention of HIV and AIDS, use of contraceptives, performance of sex, activities that take place during intercourse for example, touching, kissing and penetration by the man's penis, making babies and use of a condom. The majority of the girls used the following concepts and phrases in their description of sexuality: respecting your womanhood, making 
decisions about your future husband, maturity, getting to the stage where your hormones have started working, feelings towards a person of the opposite sex and ability to control sexual feelings.

The views of young people about sexuality could be categorised into six sub-themes namely sexuality as a private and personal matter; sexuality as a programme; sexuality as developmental, physical and emotional changes; sexuality as sexual intercourse; sexuality as living a respectable life; and sexuality as relationships.

\section{Sexuality as a private and personal matter}

Participants indicated that sexuality was a difficult matter to talk about especially with an adult. One participant indicated that sexuality was about things that could not be talked about in public, "a ti vulavuleki". Sexual experiences were mainly discussed with peers. It was believed, however, that females gave too many details about their sexual encounters, while males claimed to be conservative with details, but at the same time they exaggerated the sexual encounter. "We do talk about our sexual experiences with our peers, but sometimes we exaggerate in order to impress our peers and to earn some respect. However, as boys we do not give details the way girls do. You know Mom, if you happen to have sexual intercourse with your girl you must know that all her friends are going to know about it before the end of the day. She will give details of how it happened and her experiences. If your performance pleased her, then her friends will be kind and respectful, but if her friends always giggle when you pass them by, then you must know that you performed badly then stay away from that girl because she will humiliate you in front of your friends".

This suggests that although sexual intercourse is a private matter, discussions about it do happen among peers. According to one of the participants, discussions about sex with adults only happened during the initiation of girls and when they came home late or their parents had seen them walking with boys or even just talking to them. "...But even then, I would not say it is a real discussion because they are actually telling you how you should behave, what to do and what not do to preserve your virginity and giving you warnings about bad behaviours".
There was a view among the youth that parents or adults should have discussed sexual issues with their children before they got into sex-related problems, for example pregnancy or STIs. In other words young people preferred learning about sexuality before puberty to enable them to make informed decisions and avoid mistakes. On the other hand adults, parents included, were of the view that young people got into sex related problems because they were rebellious and do not take their teaching and guidance seriously. There was a tendency among parents and youth to blame each other for the young people's misfortunes and mistakes.

The majority of the young people were of the view that parents did not talk about sexuality because they were uncomfortable and shy to talk about sexual matters with their children. They would prefer to learn about sexuality before they make irreversible mistakes. As Newitz (1994:1) rightfully puts it, that although sexuality is about expressions of perfect human connection and relationships, it is often viewed in many cultures as a "taboo subject" and portrayed as "a shameful and abjectly terrifying experience".

\section{Sexuality as a programme}

Some participants understood sexuality as life orientation, guidance and health education programmes. The reason for this could be the fact that sexuality was taught in these programmes. To them sexuality was synonymous with the programme. The problem with equating sexuality with a programme was that sexuality tended to be discussed during the activities of that particular programme and the information gained might not be used in a normal life situation because it belonged to the life orientation or guidance or health education period or lesson.

\section{Sexuality as developmental, physical and emotional changes}

Some participants viewed sexuality as developmental changes, for example, changes in appearance, becoming a teenager, starting to get periods and starting to have wet dreams. In one focus group discussion a young man indicated that sexuality was when a boy started developing feelings for the opposite sex. This suggested that sexuality was the period when, as young people, they start making some personal choices and decisions about their lives. "Hi loko u zela u fika ka xiteji xa kondlo andzi dyi" which means literally, "It is a stage at 
which you start saying I do not eat mice". This suggested that sexuality was a developmental stage or a period of time where the youth started making choices and decisions for themselves. In all the focus groups sexuality was described by some participants as the period where young people started to develop feelings for the opposite sex, started taking good care of their personal hygiene (keeping themselves clean, starting to groom themselves) and becoming attractive. In the majority of the focus groups sexuality was perceived as developing trust in themselves, and at the same time seeing parents and other adults as backwards, old-fashioned people. Most of the examples given about the "trusting themselves" referred mainly to rebellious and aggressive behaviour towards their parents and other adults.

\section{Sexuality as sexual intercourse}

In all the focus group discussions, interviews with keyinformants and with pregnant young women, sexuality was perceived as sexual intercourse between a woman and man. This was often referred to as "Timhaka ta masangu". A key-informant indicated that she had a problem with the way sexuality was discussed over the radio, because it encouraged young people to be sexually active by using a phrase that suggested that female-male relationships were "issues of the grassmat" - sexual intercourse. Another issue that was of concern to her was that those radio lessons encouraged young people to use condoms and contraceptives, which meant they should go out and have sex.

One of the focus group discussion participants (male) indicated that sexuality was about reproduction and making of babies. It encompassed all activities before having sex (foreplay), for example, kissing and touching. Another participant perceived sexuality as using condoms, contraception, not having sexual intercourse during menstruation and different positions of intercourse. Sexuality was about the prevention of sexually transmitted diseases, for example, STIs, HIV and AIDS, syphilis and gonorrhoea, and wearing a condom.

\section{Sexuality as living a respectable life}

Sexuality was viewed by some young people as living a respectable life by maintaining virginity, having control over their own sexual feelings, having control over their sexual desires, respecting their womanhood and prevention of STIS and HIV and AIDS. It was about fol- lowing their parents' wishes, listening to their parents when they guided them, following what the Bible said, living according to what the Word preached, no sex before marriage, respecting themselves and waiting for Mr Right to take them to the altar in church. According to the African Youth Alliance ([Sa]:2) gender norms influence the developmental changes of young people by inhibiting their self-confidence and access to information and opportunities to gain skills. They restrict girls' communication and negotiation skills and therefore promote male domination in intimate and sexual relationships.

Although in some cases young people could not differentiate between assertiveness and aggression or rebelliousness, the participants' perceived sexuality as being assertive. Participants described assertiveness as having self- confidence, good self-esteem, trusting oneself, trusting one's feelings, and being proud of oneself. Others viewed it as the following: making decisions for themselves; refusing to be told what to do (rebelliousness), rebellious reactions towards education related activities and reprimands from parents.

\section{Sexuality as a relationship}

Some participants viewed sexuality as a relationship between a boy and girl, making decisions about who should be one's partner, seeing people of the opposite sex as human beings and respecting each other, including one's girlfriend. Two male participants indicated that they hated women, including their sisters. However, they both indicated that they did not hate their mothers. It was indicated by the participants that a change in attitude was necessary to have a harmonious life with a member of the opposite sex. They also indicated that men who hated women usually became abusers and serial killers. When asked about samesex relationships they seemed to have doubts about its occurrence, especially among women. They giggled among themselves about it. One of the participants said, "I understand how men can have sex, because I have heard that in prison inmates use the anus to have sex. What I do not understand is how two women can have sex, because none of them has a penis". The discussion above indicated a narrow view of what sex was all about. Furthermore, in this instance, penile penetration of the vagina or anus was viewed as sexual intercourse. Self-pleasure and other sexual activities with no penile penetration were not viewed as 
sex. This discussion limited sexual expression to heterosexual activities, therefore making women's sexual pleasure dependent on men. According to Aldepot (1993:7), limiting sexuality to intercourse is patriarchal and it interferes with the sexual development of women. According to Peck (2003:1), sexuality includes the individual's personality, thoughts, values and feelings. It is about how an individual communicates and expresses her-/himself in her/his relationship with others as well as the individual sex drive and sexual activities. In other words, sexuality is not just a relationship between sexual partners but a relationship with other people, including family members.

\section{Factors influencing sexuality/factors en- couraging sexual activities}

According to Arnfred (2004:167) sexuality is influenced and constantly reshaped by cultural, economic, familial and political relations conditioned through prevailing social organisations of gender, race and class relationships. These factors can influence sexuality positively or negatively.

The following factors were identified by both adults and youth as factors that influence youth sexuality positively and/or negatively: peers (negative and positive); puberty rites (negative and positive); financial and material gain (negative); availability and display of condoms (negative); poverty - to get a plate of food (negative); sexual assault (negative); television (TV) (negative and positive); the child support grant (negative); puberty rites for girls (negative and positive); teachers and pastors (negative and positive); bashes (negative); magazines (negative and positive); and books (negative and positive). The factors identified in the villages have very close similarities to those discussed by Arnfred above. These factors can also be classified into socialpolitical, economic, cultural and familial relations.

\section{Peer pressure}

Peers were viewed by the majority of the participants, both adults and youth, as the major factor that influences youth sexuality both negatively and positively. Magazines and books were viewed as least influential, but having both negative and positive influence. It is important to mention that these magazines and books were mainly accessed through peers who had access to bookshops or libraries.
Many studies indicate that peers have a profound influence on young people's sexuality. For example, in a study conducted by Duncan-Ricks (1992:319) at a high school in Manhattan the majority of the girls were influenced by their peers when they decided to become sexually active. In a South African study by Pettifor, Rees, Steffenson, Hlongwa-Madikizela, MacPhail, Vermaak and Kleinschmidt, (2004:60-61) peer pressure was found to be the major factor influencing youth to have sexual intercourse. However, peers can also be used to educate young people on healthy sexual behaviours. They can, for example, be used as peer educators for sexual health or life skills. In this instance the peer educators will be influencing their peers' decisions by providing accurate information and skills which can be used to make responsible sexual decisions.

\section{Television}

Television was mentioned as having negative and positive influences by both youth and adults. One keyinformant indicated that she had a problem with TV. However, as she was explaining her problem, it became clear that she was uncomfortable with her daughter who was always going out to a boy's home to watch TV at night. Her problem was not related to the programmes that are shown on TV. The media has been identified as one of the factors influencing teen sexuality, negatively or positively, because of the tendency among young people to believe that the type of behaviour that is portrayed by the media is normal and they should therefore not deviate from the portrayed behaviour. Given the influence the media has on young people it can be used to promote healthy sexual behaviour depending on the type of standards and norms that the particular media observes (Free Essays, 2006:1).

In this study some key-informants and youth had problems with some programmes and movies that young people watched on TV. They were seen as having a negative influence on the sexuality of young people. They also mentioned that there were many TV programmes that taught young people good things. Their problem was that many teenagers did not watch those programmes, but they rather wanted to watch sex films which had a profound influence on their sexuality. According to Bordo (2002:1), there are mainly two things that profoundly influence youth sexuality: popular culture and television. Through pictures and images young 
people (negatively or positively) learn about femininity, masculinity and relationships (negatively or positively) and verbal instructions no longer play a vital role in their learning.

\section{Musical lyrics}

Some young participants mentioned that the lyrics in music also influenced young people's sexuality. Gospel music and traditional Xitsonga songs were mentioned as examples of songs that could influence youth sexuality positively. Certain songs and music videos were identified that encouraged violent sexual behaviour and lack of respect for women. Free Essays (2006:1) also indicates that music has an impact on young people's sexuality. Most teenagers listen to some kind of music that have obscenities and vulgarities which could be perceived by young people as normal and they could try to behave according to the lyrics of their favourite music. However, music and music celebrities could be used to convey accurate information and skills to enable young people to make informed decisions about their sexuality.

\section{Parents}

It was indicated in the focus groups that parents contributed a great deal to the sexuality of the youth. Their contribution was both negative and positive. However, the majority of the young people mentioned mainly negative contributions. The young people who mentioned positive contributions from their parents were girls who had earlier on indicated that their mothers were their role models. These are some of the negative contributions: "Sometimes parents accuse you of being sexually active when you are not. They can even beat you up when you come home late saying you were with boys. That makes you do it so that they can be punished for something you have done". "... The problem with parents is that they wait until they catch you doing something wrong and pounce on you like you have committed a crime. They do not even listen to your explanation they just jump to conclusion. If you have strict father he can even beat you for something that you did not do. Sometimes they make you want to go all the way in order to be beaten for something you have done".

The above comments indicate a deficiency in the parent-child relationship which mainly affects girls and has a negative impact on their sexuality. It also indicates that some girls experience violence at home which sometimes leads to their running away from home to live with strangers. It also shows that openness and trust among parents and daughters can lead to a good relationship and boost the girls' self-confidence. Another observation that needs to be highlighted is that none of the key-informants complained about boys going out with girls or coming home late or bringing girls home to watch TV with them. There seems to be a general acceptance that boys should have girlfriends, but not the other way round. In other words, parents are very strict and vigilant when it comes to girls but very understanding and lax when it comes to boys' activities.

The socialisation of young people has an impact on their expression of sexuality. The lack of trust in girls has a negative impact on their expression of sexuality. According to Leichhardt Women's Community Health Centre (Sa:3), many women do not know their sexual capabilities because of social conditioning about women's sexuality. The societal expectation that a woman should play a passive role during sexual intercourse has robbed women of their responsibility to make choices about their sexuality and sexual life. Since sexual development is a life-long process, it is advisable for children to learn about it at home. As indicated in the discussion with the participants, many parents were not ready to teach their children about sexuality. Most parents gave very little information due to shyness or lack of sufficient knowledge about the subject. It is important to create opportunities for parents to learn about the subject (Robinson, 2002:2).

According to Adamson, Clemente, Gittens, Little, Doody and Simms (2001:4), many parents are uncomfortable and embarrassed about talking to their children about sexuality, because they are not confident that they have the knowledge and information to teach their children about sexuality. Many studies suggest that young people who have had parents who discuss sexuality with their children are more likely to delay sexual intercourse and use protection than children who have no guidance from their parents. There is a need for parents to have knowledge about sexuality and share their views and values with their children. There is also a need for parents to move beyond talking about sexuality as personal hygiene and abstaining from sex and how to use protection to the development of their 
children's self-esteem, to encourage a healthy respectful relationship and give a clear message that will enable young people to make healthy sexual decision.

The lack of access to sexuality information has a negative impact on family relationships, the self-concept and self-confidence of both the young people and their parents. It is important to equip parents and teachers with information and education on sexuality to ensure that young people receive the best possible information about sexuality. This will remove obstacles that make young people uncomfortable about themselves, their bodies and their relationships. Furthermore, getting sexuality information from the adults they trust will make them grow to be responsible adults who know their rights and respect those of others.

\section{Availability and display of condoms}

The availability and display of condoms were viewed by the key-informants as having a negative influence on young people. Young people engage in sexual activities because condoms are readily available for them to use. In their view young people should not engage in sexual activity until they have reached adulthood and condoms should only be available to adults.

\section{Poverty}

Poverty was mentioned as a contributory factor to negative sexual behaviour and activities. Young people subject themselves to unsafe sexual behaviour in order to earn some money to support themselves or their families. "...some girls sleep with rich men in order to get money or hoping that they will marry them and therefore run away from poverty".

Access to the child support grant was mentioned as a contributory factor to young girls' getting some money to support themselves. What was interesting about the grant was that the money is not used for the children's needs but for the mothers'. There was also a view that some girls were pressured by their parents to have children in order to access the grant money and pay for her own school fees. This was used as a way of reducing parental support and responsibility. The male participants felt that as males they were being used by girls to access the grant.

\section{Teachers and pastors}

Teachers and pastors were indicated as having both negative and positive influences on the sexuality of young people. Teachers were categorised into good and bad teachers. Good teachers were indicated as those who taught them life orientation and how to protect themselves from diseases and abuse. The bad teachers were those who abused, impregnated, and sought sexual favours from learners at school and in the community or impregnated a school girl and threatened the girl's boyfriend into claiming paternity. It was also indicated that there were pastors who abuse girls and boys inside the church and in the community.

\section{Bashes (parties)}

Bashes are all-night drinking, loud music and dancing events that happen in open spaces, for example, stadiums, streets or fields (in rural areas). Bashes were viewed by both young people and adults as having a negative influence on the sexuality of young people, because many young people are raped during these events. Some young people use these occasions for financial gain through sex for payment (in money or kind) and prostitution. This practice exposes them to unprotected sex, which might lead to the spread of STIs and HIV infections.

Some participants indicated that since the majority of the people who attend these parties are adults who own cars, young people are attracted by the big cars and "good" food that these adults bring along and end up being their sex slaves. "Every time there is a bash you have to go otherwise you will be assaulted or killed because you have eaten his money. This people do not give you their money for nothing. They even threaten your parents if they prevent you from going. They are dangerous!"

\section{Religious beliefs and rites of passage}

Religious beliefs and rites of passage were viewed as having both a negative and a positive influence on the sexuality of young people. One of the key-informants indicated that in their church they had youth programmes where they taught young people life skills, and about STIS, HIV and AIDS and the significance of no sex before marriage. Puberty rites for girls were viewed by both young people and key-informants as having both negative and positive influences on sexuality. Some girls indicated that the puberty rites encouraged them to remain virgins. This was supported by a keyinformant who indicated, "In vukhomba (puberty rites 
for girls) we teach our initiates to remain virgins...".

This key-informant further expressed some frustration at the fact that some girls attended the initiation when they were already sexually active, in other words, teaching about maintaining their virginity becomes irrelevant for those who are already sexually active. "... but as many of them are already sexually active when they are initiated I think it becomes useless because they have already tasted it. Telling them not to during initiation will not change anything".

In a study conducted by Clapp, Helbert and Zizak (2004:1-2), young people in religious organisations that provided information about STIs and contraception were less likely to have sexual intercourse than the youth who did not have access to such information. However, these teenagers were involved in other sexual behaviours, including oral sex, thinking that they were protecting themselves against STIs. In other words, involvement of youth in faith-based organisations does not necessarily prevent young people from participating in sexual activities.

The discussion above shows that religion can delay the individual's sexual debut, but does not necessarily provide young people with the knowledge and skills to make decisions about their sexuality and how to protect themselves against STIs and unwanted pregnancy. Furthermore, it shows the impact that religion has on the sexuality of the individual and how societal reaction to young people who transgress against the norms and values of society can affect the lives of young people. Aldepot (1993:5) argues against the denial of women's sexuality because it blocks their development and powers. This applies to all young people. The continuous suppression of their feelings for religious reasons can interfere with their growth and development. It can also destroy their self-concept and self-esteem. Sexuality is a powerful force that is capable of breaking all barriers, opening the self to connect with human beings and experiences.

One of the key-informants mentioned that initiations had a negative influence on the young people. "It looks like vukhomba is teaching girls not to respect men anymore. I think there is something that they teaching them that make them not to respect us. They do not care. They can say anything to you and they are not even scared to use obscene language too". "When boys come back from Matlala (circumcision) they want to be treated like vo-papa (grown up males). They do not want to go and fetch water anymore. They have lots of demands and question everything that girls do at home. They even try to control their elder sisters and their mothers at home. They start coming home late and nobody says a thing about it".

It seems religion and rites of passage in this case have an anti-sex morality value for young people. According to Fine (1988:32) morality introduces a notion of sexual subjectivity for women. Women's sexual decisionmaking is only valued if the decisions made are for premarital abstinence. Issues of sexual desire are never discussed and young women are expected to suppress such feelings. This has an impact on how young women reflect on their sexuality, therefore leading them to a position of receptivity. Acknowledgement and discussion of the existence of sexual desire could lead to healthy sexual development among the youth (Fine, 1988:32).

\section{Sexual desire}

Sexual desire was mentioned as one of the factors that influence young people's sexuality. Young people felt that sexual desire was a normal phenomenon that occurs in both females and males once you have reached puberty as it is caused by hormonal changes that occur at that stage. In their view sexual desire cannot happen before puberty, therefore sex among younger children is not sex. They are just imitating what they have seen. Furthermore, it was indicated that sexual desire was controllable, but there were situations that made control difficult, for example, sitting close to one's partner, touching, talking to him/her over the phone or caressing each other. It also happened when watching movies (soap opera, pornography or just a sexy movie).

Although all participants acknowledged the existence of sexual desire or rather sexual arousal, some felt that it should be suppressed until such time as the individual was ready to have sex. The majority of the male participants expressed difficulty in suppressing sexual desire. Some participants indicated that the Christian religion could assist young people in controlling their sexual desire.

According to Surgey (1996:2), women who attempt to assert their sexual autonomy usually come up against 
strong opposition from family and society that seek to control it. As sexuality is about personality, communication and how an individual expresses her-/ himself in relationships with others, it is important to give young people information about sexuality and give them space to make decisions about their own sexuality. Sexual health programmes should promote a partnership between young people and adults to ensure that young people make informed choices, enjoy their sexuality and fully participate in the community activities. A safe supportive environment with trusted adults will make them develop into responsible young people who can communicate and express themselves responsibly at all times.

\section{CONCLUSION}

The findings of the youth's perceptions regarding sexuality revealed a varied understanding of the concept sexuality. Their discussion of sexuality, however, was mainly related to heterosexual sexual activity. This could be an indication that the sexuality information available to them is on sexual intercourse. There is a need to include a holistic view of sexuality in sexuality education programmes to provide accurate information and assist the youth in acquiring skills that will help them make responsible decisions about their lives.

The young people's perception of sexuality as a private and personal matter makes it difficult to discuss sexual issues with other people and might have a negative impact on their health-care seeking behaviour when experiencing problems related to their reproductive system.

Although there are many factors that influence the sexuality of young people negatively or positively, it was evident that peers had more influence than other factors. It is therefore important that young people should have access to accurate information about sexuality so that accurate information is disseminated. The lack of trust between parents and youth has a negative impact on the flow of information necessary for healthy sexual behaviour among young people. There is a need to educate parents and other significant adults on how to relate to young people and how to handle issues of sexuality among them. Furthermore, the need to understand the young people's perspective on sexuality and to develop programmes that address their needs cannot be overstated.

\section{LIST OF REFERENCES}

ADAMSON, D; CLEMENTE, A; GITTENS, M; LITTLE, W; DOODY, L\& SIMMS, M 2001: Hey, what do I say? A parent to parent guide on how to talk to with your children about sexuality. New York: Planned Parenthood Association.

AFRICAN YOUTH ALLIANCE, [Sa]: Gender. African Youth Alliance. Available at www.ayaonline.org/strategies/gender.htm. (Accessed 23 August 2005).

ALDEPOT, N 1993: Sexuality: An empowering force in the work of women and health in the Dominican Republic 1984-1990. Paper delivered at the 5th Interdisciplinary Congress on women in Costa Rico: Conference Proceedings.

ARNFRED, S 2004: Re-thinking sexualities in Africa. Uppsala: Nordic Africa Institute.

BORDO, S 2002: Love lies and fantasy a cultural analysis. Teen sexuality in a culture of confusion. Available at http// www.intac.com/ jdeck/habib/overview/ov3.html. Accessed 25 May 2005.

CLAPP, S; HELBERT, KL \& ZIZAK, A [Sa]: Faith matters: Teenagers, religion, and sexuality. Available at www.churchstuff.com/ faithmatters.html. (Accessed 23 August 2005).

CRESWELL, JW 1994: Research design: Qualitative and quantitative approaches. Thousand Oaks: Sage.

CREWE, M 1996: Why is the subject of sex education for youth so difficult to deal with? A journey to honesty. Sexual and reproductive Health Bulletin, 3 September 1996:8-9.

DEPARTMENT OF HEALTH 2007: National HIV and syphilis prevalence survey South Africa 2006. Pretoria: Government Printers. DUNCAN-RICKS, E 1992: Adolescence Sexuality and peer pressure. Child and Adolescent Social Work Journal, 9(4):319327. Available at www.springerlink.com/content/ p2873361l1751753/. (Accessed 17 March 2007).

FINE, M 1988: Sexuality, schooling and adolescent females: The missing discourse of desire. Harvard Educational Review, 58(1):29-53.

FREE ESSAYS, 2006: Sex pressure. Available at www.freeessays.cc/db/39/pnl262.shtml. (Accessed 15 March 2006).

GoOSEN, M \& KLUGMAN, B (eds) 1996: The South African women's health book. Cape Town: Oxford University Press.

HUDELSON, PM 1994: Qualitative research for health programmes. Geneva: World Health Organization Mental Health Division. INTERVENTION FOR SUPPORT HEALING AWARENESS (IFSHA), 2005: Sexuality. Available at http://www.ifsha.org - SEX GLOSSARY. (Accessed 15 March 2006).

INTERNATIONAL PLANNED PARENTHOOD FEDERATION 2002 
Adolescent sexuality, gender and the HIV epidemic. AIDS Summary, No 6:1-4. www.ippfwhr.org/publication/serial_article_ e.asp?PublD-20\&serialissuesID=91\&articleID=18 (Accessed 23 August 2005).

KENYA WOMEN'S INTERNATIONALASSOCIATION, 1993: A comprehensive report to women's health. Report of the First Regional Congress of the Medical Women's International Association, Near East and Africa. Nairobi: Medical Women's International Association.

KOONTZ, S \& CONLY, SR 1994: Youth at risk: Meeting the sexual health needs of adolescents - Questions and Answers. Population Action International, April:1-5.

LEICHHARDT WOMEN'S COMMUNITY HEALTH CENTRE, [Sa]: Sexuality. Leichhardt: Leichhardt Women's Community Health Centre. MAIER, B; GORGEN, R; KIELMANN, AA; DIESFELD, HJ \& KORTE, R 1994: Assessment of the district health system using qualitative methods. London: Macmillan Press.

MALULEKE, TX 2003: The views of women in the Limpopo Province of South Africa concerning girls' puberty rites. Health SA Gesondheid, 8(3):47-60.

NATIONAL FEDERATION OF RED CROSS AND RED CRESCENT SOCIETIES [Sa]: An introduction to sexual health. Geneva: International Federation of the Red Cross and Red Crescent Societies. NATIONAL YOUTH COMMISSION 1997: National Youth Policy. Pretoria Available at http://www.polity.org.za/ page.php?rep_id=528. (Accessed on 19 January 2006).

NEWITZ, A 1994: Why do you want to get laid? Mapping sexual geographies. Available at http://www.eserver.org/bs/17/ Newitz.html. (Accessed 13 May 2004).

O'HIGGINS, N 1997: The Challenge of Youth Unemployment. ILO Action Programme on Youth Unemployment. Available at: http:// www.ilo.org/public/english/employment/strat/publ/etp7.htm (Accessed 23 August 2005).

PECK, L 2003: Sexuality and Disability Fact Sheet. Available at: http://www.mossresourcenet.org/sexuali.htm. (Accessed 19 January 2006).

PETTIFOR, AE; REES, HV; STEFFENSON, A; HLONGWAMADIKIZELA, L; MACPHAIL, C; VERMAAK, K \& KLEINSCHMIDT, I 2004: HIV and sexual behaviour among young South Africans: A national survey of 15-24 year olds. Johannesburg: Reproductive Health Research Unit, University of Witwatersrand.

ROBINSON, BA 2002: Human sexuality: Conflicts and consensus on youth sexuality. Ontario consultants. Available at: http:// www.religioustolerance.org/condom.htm. (Accessed 23 August 2005).

SURGEY, D 1996: Sexuality: Gender and sexual practices. Arrows for change, 2(2):1-2. 